\title{
FUTURE TIME REFERENCE IN LULE SAAMI, WITH SOME REMARKS ON FINNISH
}

\author{
Jussi Ylikoski \\ UiT The Arctic University of Norway
}

\begin{abstract}
The paper provides an account of future time reference (FTR) in Lule Saami. While previous accounts of the language claim that the Lule Saami galggat 'shall; must; intend' is a future auxiliary, there are two other potential candidates for what might be called a future tense as well. On the basis of actual language use, the potential mood in Lule Saami does not always refer to states of affairs to be understood as uncertain or only possible, but is also used to refer to future events with no visible shades of possibility or other modalities. Special attention is given to another grammaticalized construction, a periphrastic form consisting of the copula liehket 'be' and a purposive converb (supine). Further, it is shown that the Lule Saami supine construction has a formal and functional analogue in the previously undescribed, future-like aspectual functions of the purposive converb in Finnish.
\end{abstract}

Keywords: future tense, future time reference, converbs, potential mood, prospective aspect, Lule Saami, Finnish

DOI: http://dx.doi.org/10.12697/jeful.2016.7.2.09

\section{Introduction}

Like most Uralic languages, Saami languages are not famous for having future tenses, regardless of how future tense is defined. Instead, Saami languages are barely mentioned in studies on Uralic future time reference (Majtinskaja 1973, Metslang 1996, and Norvik 2013, 2015), and likewise, futures and futurity are seldom mentioned in descriptions of tense systems or modality of Saami languages. It appears that the most important reason for this is the fact that indisputable future tenses are, indeed, absent in Saami languages. However, the present paper provides a short descriptive account of two overlooked types of future time reference in Lule Saami, one of the lesser-studied Saami languages as regards morphosyntax and sentential semantics.

The structure of the paper is as follows: After a brief introduction to Lule Saami and earlier statements on the future tense based on the verb 
galggat 'shall; must; intend' (Section 2), Section 3 provides new information about the use of the so-called potential mood in functions that are better understood as explicit references to future time rather than as expressions of possibility. In Section 4, the discussion is extended to functionally similar periphrastic expressions consisting of the copular verb liehket 'be', which functions as an auxiliary to the lexical verb in the so-called supine form in -tjit/-ttjat, otherwise a purposive converb with partly infinitival functions. Section 5 draws the three future time reference devices together and discusses their differences and similarities. Special attention is also given to a poorly described future-like construction in Finnish, as the Lule Saami supinal future construction is also structurally similar to the use of the Finnish purposive converb in -takse- with the copula olla.

As often is the case with expressions that could be characterized as future tenses, all of the verb forms discussed here are functionally intertwined with various shades of modality such as intention, possibility and necessity. Furthermore, it is often difficult to make a distinction between the idea of a future tense and expressions of aspect under labels like immediate future or prospective aspect. The concept of a future tense is notoriously difficult and controversial for a variety of reasons, but instead of contributing to theoretical controversies, the main purpose of the present paper is simply to provide the first systematic account of future time reference in Lule Saami, and, most importantly, to describe some of the previously unnoticed grammatical future time reference devices in the language for the very first time. To this end, the theoretical basis of the description is largely identical to the discussion on future time reference and the so-called future time reference (FTR) devices as defined and used by Metslang (1996), Dahl (2000) and Norvik (2013, 2015). Following Norvik (2015: 13), the term FTR device is used here "because it does not presuppose that the device under discussion is a grammaticalised future marker" but rather a grammatical device or a "gram" - including the so-called present (non-past) tense in Lule Saami - that may be used to refer to future events and actions even though various shades of modality and aspect cannot be necessarily delineated outside the temporal interpretations.

The majority of the data and information comes from the multigenre text corpus of Lule Saami (nearly 800,000 words), originally published within approximately the past three decades and made available by the SIKOR corpus at UiT The Arctic University of Norway. As for the genres included in the corpus, the subcorpora have been 
labeled as administrative, religious, non-fiction, fiction, legal, newspaper and scholarly texts. Only a minor part of fiction is based on oral folklore. The data sources also include various other texts, such as the earliest authentic stories in Lule Saami (Halász 1885, Qvigstad 1929). Although much of the data comes from a comparatively large corpus with respect to the size of the language community, this study is almost exclusively qualitative in nature. It has not been possible to extend and diversify the topic and methods of the present observational description of written language data to the study of spoken language or a pursuit of grammaticality judgments by native speakers within the confines of this study. ${ }^{1}$ For the purposes of the present paper, the orthographic variation resulting from earlier scholarly transcriptions and orthographic standards has been reduced to a minimum by transforming nearly all data to the present standard orthography.

\section{History of research: Future auxiliaries in the Saami grammatical tradition}

Lule Saami, spoken in the Nordland County of Norway and the Norrbotten County of Sweden, is the nearest sister language of North Saami and structurally even closer to Pite Saami, a highly endangered language spoken south of Lule Saami. With approximately one thousand speakers, Lule Saami continues to be transmitted to new generations and has an established status as a literary language. However, although Lule Saami and North Saami are nowadays kept strictly apart and generally regarded as two distinct languages, there is still no full consensus on the exact border between the two languages. ${ }^{2}$ On the other hand, as North Saami currently enjoys the privilege of being the foremost indigenous language of Norway, Sweden and Finland, the description of Lule Saami has not been in the main focus of Saami linguistics since Halász $(1881,1885)$ and Wiklund's $(1890,1891,1915)$ pioneering work more than a century ago. Most of our current understanding of Lule Saami grammar is based on early descriptions by Wiklund $(1891,1915)$

1 I wish to express my thanks to Inga Lill Sigga Mikkelsen, Heidi Niva and the two anonymous reviewers for their valuable comments on earlier versions of this paper, and edna gijtto to Inggá for insightful and inspiring comments about my findings and emerging intuition about her language.

2 For diverging dialectological approaches to the issue, see Wickman (1980), Sammallahti (1998: 19) and Rydving (2013). 
and a later school grammar - clearly influenced by the North Saami grammatical tradition - by Spiik (1989).

In Saami linguistics, it is customary to view the TAM categories as more or less identical to those of the Finnic languages: Most Saami languages have four moods (indicative, imperative, conditional and potential) and two inflectional tenses - the present and the past. In addition to these, past participles are combined with the copulas to form periphrastic tenses labeled as perfect and pluperfect. As such, these tense systems appear to be quite similar to those in the neighboring Scandinavian languages (Norwegian and Swedish) and other Germanic languages. ${ }^{3}$ However, especially Lule Saami grammars make an exception in presenting also a future tense, a periphrastic verb form consisting of the auxiliary galggat and the lexical verb in the infinitive in -t. This tradition goes back to Halász's (1881: 59-60) and Wiklund's (1891: 271, 1915: 81) early descriptions of the grammar and is repeated in Spiik's (1989: 75 ff., 103-104) modern school grammar. The most recent school textbooks also include the "second future", in which the auxiliary is in the past tense (Andersen 2002b: 63, 2004: 112-113); this will be discussed from an aspectual point of view in Section 5 below:
a. Sijdan galggap guolijt bårrait. ("the first future") home.INE shall.PRS.1PL fish.PL.ACC eat.INF
'At home, we are going to eat the fish.' (Andersen 2004: 113)
b. Sijdan galgajma guolijt bårrait. ("the second future") home.INE shall.PST.1PL fish.PL.ACC eat.INF

'At home, we were going to eat the fish.' (Andersen 2004: 113)

However, the above-mentioned grammars pay little attention to the fact that future time reference is only one of the many functions of this construction, or, more precisely, of the modal verb galggat 'shall; must; intend', which almost always takes the infinitive as its complement. On the other hand, not unlike in most Uralic languages as well as in the neighboring Scandinavian ones, the so-called present tense in Lule Saami is actually a non-past tense that may also refer to future

3 The apparent similarity of the Saami and Scandinavian tense systems is less obvious if one takes into account the progressive periphrastic forms (to be discussed in Section 4), in which the lexical verb is in the progressive non-finite form, traditionally enigmatically labeled as the "actio essive" (see Korhonen 1974: 94ff., Ylikoski 2009: 40). 
events. As seen in (2), the alleged "future" based on galggat is also used to express modal meanings such as intention, obligation and necessity (prohibition):

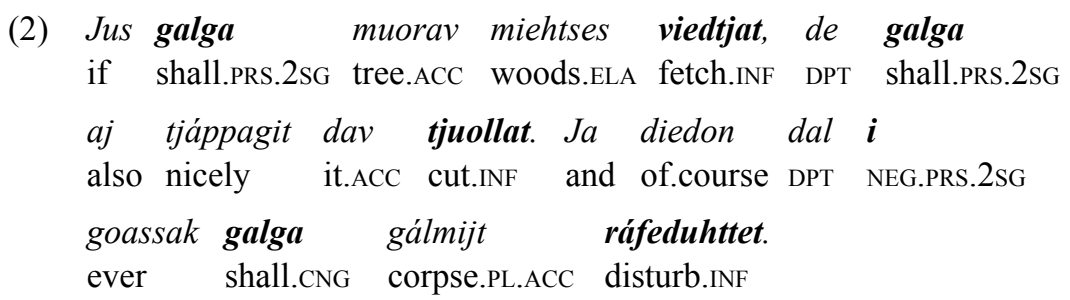

'If you are going to fetch a tree from the woods, you must cut it cleanly. And of course, you must never disturb corpses (buried in the woods).' (SIKOR)

In a nutshell, the functions of galggat are quite identical to those of skulle and skola in Norwegian and Swedish, respectively (see, e.g., Faarlund et al. 1997: 604-612 for Norwegian). For example, galggat is also used without any verbal complements to express intended motion to a specific goal such as school in (10) below (cf. Dahl 2000: 326, Note 2 for Scandinavian). As virtually all Lule Saami speakers are bilingual in Norwegian/Swedish, remarkable interference from the majority languages occurs on all levels of the language, and modal verbs are no exception. Similar tendencies can be observed in Pite Saami and in most of North Saami, mainly spoken in Norway and Sweden (Koskinen 1998: 38-56, Wilbur 2014: 156-157, 241). Apparently, the recent development of galggat and its cognates such as Pite Saami gallgat and North Saami galgat may be partly due to the phonological similarity of the Saami verbs and the Scandinavian verb in its present tense form (Norwegian skal, Swedish ska(ll)). ${ }^{4}$ What is more interesting, we are here observing a situation in which an ancient Indo-European loan in Uralic (including

4 Example (i) from Norwegian North Saami crystallizes the fact that galgat is partially losing its modal functions to the benefit of verbs like fertet 'must; have to'. However, galgat has not become an obligatory FTR device; rather, the so-called present tense is best understood as non-past in North Saami as well.
(i) Galgat $=$ go mii álgit vai eat $=g o \quad$ álgge?
shall.PRS. $1 \mathrm{PL}=\mathrm{Q} \quad 1 \mathrm{PL} \quad$ begin.INF $\quad$ or $\quad \mathrm{NEG} .1 \mathrm{PL}=\mathrm{Q}$ begin.PRS.CNG
$\begin{array}{lllllllll}\text { Jus } & \text { mii } & \text { galgat } & \text { álgit, } & \text { de } & \text { mii } & \text { fertet } & \text { álgit } & \text { dál. } \\ \text { if } & 1 \mathrm{PL} & \text { shall.PRS.1PL } & \text { begin.INF } & \text { DPT } & 1 \mathrm{PL} & \text { must.PRS.1PL } & \text { begin.INF } & \text { now }\end{array}$
'Are we going to begin [to raise money for a school class] or not? If we are going to begin, we must begin now.' (A speaker of North Saami in Guovdageaidnu, Norway, 2011; personal observation) 
Hungarian kell 'must', for example) has come into close contact with its distant relatives in modern Scandinavian descendants of PIE

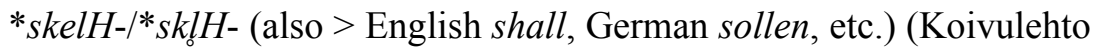
2001: 236-237). As the functions of the Scandinavian and Saami verbs have gradually become more and more similar, it appears that the etymological circle is, in a way, closing.

While it appears that galggat + infinitive is, indeed, perhaps the most frequent grammatical FTR device in Lule Saami, it is important to understand that it is far from being a true future tense. Rather, it is a multi-purpose modal construction headed by the multi-purpose modal verb galggat 'shall; must; intend; etc.' whose usage is greatly affected by the corresponding verbs in the Scandinavian majority languages. The construction is not on a par with the inflectional present and past tenses, but is rather an optional alternative to the present tense that would be better characterized as a general non-past tense. While the actual use of galggat would merit a detailed study in itself, the following sections provide more novel information about other functionally similar but historically more autochthonous and structurally more grammaticalized FTR devices in Lule Saami.

\section{The so-called potential mood in Lule Saami: a mood or a tense marker?}

Like the verb galggat, the so-called potential mood in Lule Saami goes back to Proto-Saami and has survived to some degree in most Saami languages. The functions of the Saami potential have been described quite extensively by Bartens (1980), but he pays next to no attention to the potential in Lule Saami in particular. In Lule Saami, the potential mood marker is - $(t) t j-/-(\check{c}) \check{c}-/($ IPA $/ \widehat{t f}(:) /)$ followed by person suffixes for all persons except for the zero-marked third person singular, which ends in the potential marker $-s j /-\check{s} /($ IPA / $/ /)$. The potential is regarded as a mood without tense distinctions, and - unlike in North Saami - the present vs. past tense distinction applies to the indicative only (Table 1). In other words, the potential forms are in paradigmatic contrast with the present and past indicative. 
Table 1. The inflectional paradigms for the verb tjállet 'write' in the present and past indicative and the so-called potential mood.

$\begin{array}{llll} & \text { Present indicative } & \text { Past indicative } & \text { Potential } \\ \text { 1SG } & \text { tjáláv } & \text { tjálliv } & \text { tjálitjav } \\ \text { 2sG } & \text { tjálá } & \text { tjálli } & \text { tjálitja } \\ \text { 3SG } & \text { tjállá } & \text { tjálij } & \text { tjálisj } \\ \text { 1DU } & \text { tjállin } & \text { tjálijma } & \text { tjálitjin } \\ \text { 2DU } & \text { tjállebihtte } & \text { tjálijda } & \text { tjálitjihppe } \\ \text { 3DU } & \text { tjálleba } & \text { tjálijga } & \text { tjálitjibá } \\ \text { 1PL } & \text { tjállep } & \text { tjálijma } & \text { tjálitjip } \\ \text { 2PL } & \text { tjállebihtit } & \text { tjálijda } & \text { tjálitjihpit } \\ \text { 3PL } & \text { tjálli } & \text { tjállin } & \text { tjálitji }\end{array}$

As for the meaning of the potential, both Wiklund (1915: 112) and Spiik (1989: 105) use the Swedish auxiliary torde 'should, ought' and the adverbs förmodligen and nog 'probably; presumably' to characterize the meaning of the potential in sentences such as (3):
(3) Bådisj
gåjt
idida.
come.POT.3sg in.any.case morning.GeN

'S/he ought to come in the morning in any case.' (Wiklund 1915: 112)

My aim is not to present quantitative data on the functions of the potential in contemporary or earlier Lule Saami, but (3) is a quite typical occurrence of the potential as a predicate that refers to a future event that is supposed to come true (see also Tuolja \& Kuoljok 1999: 155-158, Andersen 2004: 115). However, it is equally possible to see potential verb forms in contexts where they do not refer to the future but explicitly to the present time. In (4), it is obvious that the fairy tale in question ends with a supposition that does not refer to the future but is presented as a possible state of affairs at the moment of speaking:

5 Wiklund's (1915: 112) translation into Swedish: han kommer nog, han torde komma $i$
morgon. 
(4) De báhttja usjudij: "Buorep la dal prinsessajn DPT boy think.PST.3SG good.CMPV be.PRS.3SG DPT princess.COM válldut gå råhtujn," ja de vuordij ja marry.INF than rat.COM and DPT wait.PST.3SG and tjåhkkidij voannnaj, ja de vuojijga girkkuj sit.down.PST.3SG carriage.ILL and DPT drive.PST.2DU church.ILL ja jugálvis åroj guokta vahko, ja ihkap vil and feast stay.PST.3SG two week.GEN and maybe still dálla jutsátji, guhtis diehtá? now make.noise.POT.3PL who know.PRS.3SG

'And then the young man thought: "it is better to marry the princess instead of the rat", and then he waited and sat down in the carriage and then they drove to church, and the wedding feast lasted for two weeks, and they are probably still making noise, who knows.' (SIKOR $<<$ Qvigstad 1929: 492)

On the other hand, the fairy tale has previously contained (5), and the same storyteller has also produced (6):
(5) Valla báhttja usjut sjávot: "Galla mån dal dujna but boy think.PRS.3SG quietly DPT 1SG DPT 2SG.COM válldutjav, vuorde beri!" marry.POT.1SG wait.IMP.2sG just

'But the boy thinks to himself: "I'll marry you for sure, just wait!", (SIKOR << Qvigstad 1929: 488)

(6) De javllá biernna: “Vuojnitjin måj dal goappá DPT say.PRS.3SG bear see.POT.1DU 1DU now which.GEN bahta buojdep sjaddá gå gåhttsåjin buttocks greasy.CMPV become.PRS.3sG when wake.PRs.1DU oademis." sleeping.ELA

'Then the bear says: "Now we'll see whose buttocks get greasier when we wake up from sleep."' (SIKOR << Qvigstad 1929: 472)

Unlike in (4), in Examples (5-6) the speakers present their future expectations as firmly as seems to be possible when referring to future time. In (5), the boy is not speaking about the future marrying event as a mere possibility, but rather as if he were destined to marry the 
princess he is talking about. In addition to the above examples from stories collected in the 1880 s, Lule Saami has continued to use its potential in a very similar manner through the 20th century and up to this day:

(7) Hähttutjav má mån gábmagijt goarrát, tjoaskosj must.POT.1SG DPT 1SG shoe.PL.ACC begin.to.sew.INF cool.POT.3SG gåjt dal ruvva ja dåj nuvtagijt in.any.case now soon and 2DU Saami.winter.shoe.PL.ACC dárbahihppe. need.PRS.1DU

'I'll have to start sewing shoes; it'll get cold soon in any case and you need winter shoes.' (SIKOR < Tuolja 1987)

$\begin{array}{lllll}- \text { Idisj } & \text { sån, } & \text { vuojnitja } & \text { då, } & \text { javlaj. } \\ \text { appear.POT.3SG } & \text { 3SG } & \text { see.POT.2SG } & \text { DPT } & \text { say.PST.3SG }\end{array}$

'He'll appear, you'll see, he said.' (SIKOR < Andersen 2002a)

It is not possible to go into details of the neighboring sister languages of Lule Saami, but it seems safe to state that potential verb forms that refer to future with such confidence - making the entire label "potential" appear to be a misnomer - are quite foreign to other Saami languages. In North Saami, the cognate of this Lule Saami mood might be better labeled as "dubitative" (Aikio 2009), whereas the Pite Saami potential is said to refer to future events that are presented as possible or likely to happen (Lehtiranta 1992: 88, Wilbur 2014: 154-155, 248-249).

Further, it appears that the potential mood is far more frequent and productive in Lule Saami than in any other Saami language. At least in North Saami and Aanaar (Inari) Saami in the northeast, the potential mood is largely confined to potential forms of the copulas leat and lede and a small number of other verbs, and non-dubitative references to future are rather foreign to the use of the potential mood. As for Pite Saami, the use of the potential seems to have diminished significantly in connection with language attrition (cf. Bartens 1980, Lehtiranta 1992: 88, and Wilbur 2014: 167), but Lule Saami uses its nearly identical forms to the extent that it might be justified to ask whether the potential forms should be understood as a mood or perhaps also as a kind of tense category. True, it is understandable that verb forms such as jutsátji 'they are probably making noise' (4) are regarded as manifestations of a mood other than the indicative, but on the other hand, the features that differentiate the potential forms ('I'll marry', 'we'll see', 'I'll have to', 
'it'll get cold', 'he'll appear', 'you'll see') in (5-8) from the indicative present seem to belong primarily to the realm of time reference rather than modality. Similar examples from other Saami languages have been only briefly mentioned by Bartens (1980: 23-24). ${ }^{6}$

It may also be added that the potential is also formally analogous to the indicative present and past tenses in the field of periphrastic negatives for the copula liehket, as the second person singular and third person plural negative auxiliaries $i$ and $e$ have coalesced with the potential connegative form littja to yield the specialized forms illittja and cellitja $\left(\right.$ cellittja $^{7}$ ), which are comparable to illa [be.NEG.PRs.2sG], illim [be.NEG. PST.2sG], cella [be.NEG.PRs.3PL] and cellim [be.NEG.PSt.3PL] (Table 2).

Table 2. The inflectional paradigms for the negation of the copula liehket in the present and past indicative and the so-called potential mood.

$\begin{array}{llll} & \text { Present indicative } & \text { Past indicative } & \text { Potential } \\ \text { 1 } \mathrm{SG} & \text { iv la } & \text { iv lim } & \text { iv littja } \\ \text { 2SG } & \text { illa } & \text { illim } & \text { illittja ( i littja) } \\ \text { 3SG } & \text { ij la } & \text { ij lim } & \text { ij littja } \\ \text { 1DU } & \text { en la } & \text { ejma lim } & \text { en littja } \\ \text { 2DU } & \text { cehppe la } & \text { ejda lim } & \text { cehppe littja } \\ \text { 3DU } & \text { cebá la } & \text { ejga lim } & \text { cebá littja } \\ \text { 1PL } & \text { ep la } & \text { ejma lim } & \text { ep littja } \\ \text { 2PL } & \text { ehpit la } & \text { ejda lim } & \text { ehpit littja } \\ \text { 3PL } & \text { cella } & \text { cellim } & \text { celli(t)tja }\end{array}$

In addition to being examples of celli(t)tja, (9-10) are further examples of potential forms in contexts where it would be awkward to explain the use of the potential by the need to refer to uncertainty of states of affairs such as the arrival of Christmas after the four Sundays of Advent (9):

6 Bartens' (1980: 24) only example (ii) from Lule Saami stems from a text published by Wiklund (1915: 145), but judging from its original context, his example and his German translation for it remain somewhat ambiguous as regards its modal connotations.

(ii) Båråtjip mij galle.

eat.POT.1PL 1PL DPT

'We'll eat soon.' (Bartens 1980: 24 < Wiklund 1915: 145; Bartens' translation: Wir würden schon essen.)

7 According to both Spiik (1989: 72) and Tuolja and Kuoljok (1999: 158), the third person plural form is cellittja (ällittja), but in actual usage (9-10), the word form is spelled cellitja. 
(9)

$\begin{array}{lllll}\text { - Goassa } & l i & \text { javla? } & \text { gatját } & \text { Bov. } \\ \text { when } & \text { be.PRS.3PL } & \text { Christmas(.PL) } & \text { ask.PRS.3SG } & \text { B. }\end{array}$

- Na, gå de ulmutja li tsahkkidam divna

well when DPT human.PL be.PRS.3PL light.up.PST.PTCP all

niellja ginntala, de cellitja moadda biejve vil,

four candle.GEN DPT be.NEG.POT.3PL many day.GEN anymore

tjielggi ieddne.

explain.PRS.3SG mother

'- When is Christmas? Bov asks.

- Well, once all four candles have been lit, there won't be many days left, mother explains.' (Persen 1999a: 10)
(10) $-L e$
gus ietjat
lanjáv rádjam?
be.PRS.2SG
Q REFL.GEN.2SG
room.ACC clean.up.PST.PTCP

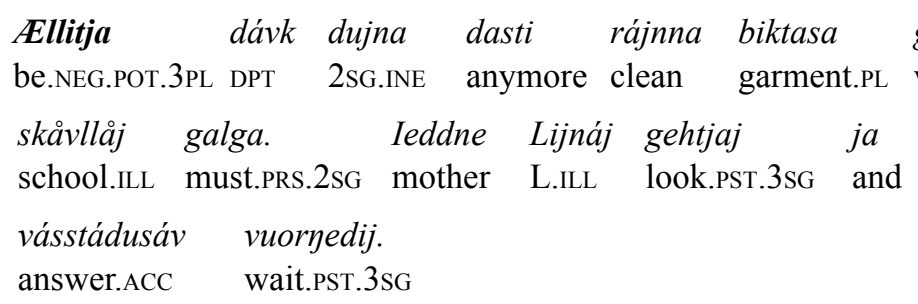

- Na rájatjav mån.

well clean.up.POT.1SG $1 \mathrm{SG}$

- Iektu aj dav javlli. (...)

yesterday also that.ACC say.PST.2SG

'- Have you cleaned up your room? You're not going to have clean clothes when you must go to school. Mother looked at Lijná and waited for an answer.

- OK, I'll clean up.

- You said that yesterday, too. (...)' (Vars 2004: 17)

More important than clear morphological analogies with indicative past and present is the mere fact that in the above examples, too, the so-called potential mood is able to refer to future events without any specific modal - or aspectual - connotations, and in so doing it is functionally analogous to the two inflectional tenses that are distinguished in the indicative only. This interpretation is also corroborated by the fact that Examples (9-10) are translations from North Saami, and the original sentences have their predicates in the present indicative - with future time reference - and do not have any other grammatical or lexical expressions of modality either: 
North Saami

(11) - Goas bat juovllat leat? jearrá Bov.

when DPT Christmas(.PL) be.Prs.3PL ask.PRS.3SG B.

$-N a$, go dal olbmot leat cahkkehan

well when DPT human.PL be.PRS.3PL light.up.PST.PTCP

buot njeallje gintala, de eai leat

all four candle.GA DPT NEG.3PL be.PRS.CNG

vel go moadde beaivvi juovllaide,

anymore (more.)than couple day.GA Christmas(.PL).ILL

čilge eadni.

explain.PRs.3sG mother

'- When is Christmas? Bov asks.

- Well, once all four candles have been lit, there won't be more than a couple of days left, mother explains.' (Persen 1999b: 10)

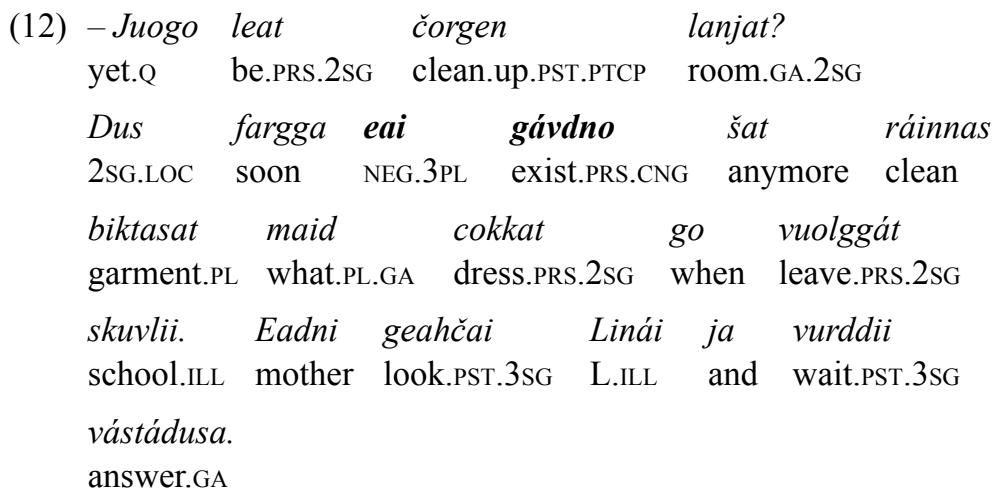

-Juo, juo, gal mun čorgen.

yes yes DPT 1SG clean.up.PRS.1SG

- Nie lohket ikte maid. (...)

like.that say.PST.2sG yesterday also

'- Have you cleaned up your room? You're not going to have clean clothes when you must go to school. Mother looked at Liná and waited for an answer.

- OK, I'll clean up.

- You said that yesterday, too. (...)' (Vars 2002: 17)

Despite the examples presented above, it cannot be denied that many occurrences of the potential mood do indeed carry modal meanings of possibility or uncertainty, and they may also refer to present events 
instead of future. There is thus no reason to attempt to fully reject the traditional view of the potential as a mood. Instead, the above examples are better understood as nearly entirely neglected evidence of the fact that the so-called potential mood in Lule Saami can also be used in contexts in which its main if not only purpose is to refer to future time.

\section{Copula + supine: a "new" periphrastic future in Lule Saami?}

Before comparing the future-like functions of the potential mood (Section 3) with the alleged galggat future (Section 2), it is important to discuss the third and the least well-known grammaticalized expression for future time reference in Lule Saami. One of the most characteristic inflectional forms in the language is the so-called supine, a non-finite that has been reconstructed for Proto-Saami but nowadays apparently occurs only in Lule and Pite Saami and the Torne dialects of North Saami (Korhonen 1974: 197-203, 1981: 298, and Bartens 1986). In the other Saami languages, most of the functions of the supine are expressed by the pan-Saami infinitive, but in addition to the infinitive in $-t$, Lule Saami makes active use of the supine in -tjit/-čit/ (IPA/ / $\left.\int i t /\right)$, or -ttjat/-ččat/(/ț:at/) for imparisyllabic consonantal stems, as a purposive converb that most often occurs with motion verbs (13) but to some extent with other kinds of predicates as well (Bartens 1986, Ylikoski 2004: 125-126, 149-150; see (15) and (16) below). Again, the general descriptions of the supine have remained scanty and unchanged from Wiklund (1915: 116) to Spiik (1989: 106), but some of the most recent school textbooks provide examples that hardly are equal to the (motioncum-)purpose clauses that are the main domain of the supine. According to Nystø (2000: 74), the supine can be used with verbs such as mannat 'go' and vuolgit 'go; leave' (13), but also with liehket 'be' (14):

$\begin{array}{llll}\text { Sajj } & \text { vuolgijga } & \text { sijddaj } & \text { lågåtjit. } \\ \text { 3DU } & \text { leave.PST.3DU } & \text { home.ILL } & \text { read.sUP }\end{array}$

'They went home to read.' (Nystø 2000: 74)

(14)

$\begin{array}{llll}\text { Ábmut } & \boldsymbol{l a} & \text { girjev } & \text { tjálátjit. } \\ \text { Á } & \text { be.PRS.3SG } & \text { letter.ACC } & \text { write.SUP }\end{array}$

‘Ábmut is going to write a letter.' (Nystø 2000: 74)

Nystø's (2000: 74) textbook translates (14) into Norwegian as Ábmut har til hensikt å skrive et brev 'Ábmut has the intention to write 
a letter', but this seems to be an unnecessarily emphatic rephrasing and a contrived attempt to make the supine look like a purposive converb; see also Tuolja and Kuoljok (1999: 150-151) with analogous examples in which the supine is claimed to express the intention or purpose of the action denoted by the governing verb. On the contrary, sentences like (14) differ fundamentally from sentences like (13) in which the supine functions as a free adverbial modifier of a well-formed main clause. While reading is the very purpose of going home in (13), writing a letter is not the "purpose of being" in (14). The elemental difference between the two uses of the supine becomes even more evident in actual language use:

\begin{tabular}{|c|c|c|c|c|c|}
\hline $\begin{array}{l}\text { Dåppe } \\
\text { there }\end{array}$ & $\begin{array}{l}\text { dat } \\
\text { it }\end{array}$ & $\begin{array}{l}\text { ittjij } \\
\text { NEG.PST.3SG }\end{array}$ & $\begin{array}{l}\text { aneduvá } \\
\text { use.PASS.CNG }\end{array}$ & $\begin{array}{l}\text { ietjas } \\
\text { REFL.ACC.3s }\end{array}$ & \\
\hline $\begin{array}{l}\text { jámálg } \\
\text { cause.t }\end{array}$ & tváda & $\begin{array}{ll}\text { htátjit, ájnat } \\
\text { SUP } & \text { but }\end{array}$ & $\begin{array}{l}\text { bäjvvásattjat, } \\
\text { daily.ADV }\end{array}$ & $\begin{array}{l}\text { vaj } \\
\text { so.that }\end{array}$ & $\begin{array}{l}\text { diehtin } \\
\text { know.PST.3PL }\end{array}$ \\
\hline $\begin{array}{l}\text { gåktu } \\
\text { how }\end{array}$ & & $\begin{array}{l}\text { lij } \\
\text { be.PST.3sG }\end{array}$ & $\begin{array}{l}\text { sjattatjit. } \\
\text { become.SUP }\end{array}$ & & \\
\hline
\end{tabular}

'There it [the shaman's drum] was not used in order to get into a trance, but on the daily basis, in order to know how life was going to be.' (SIKOR)

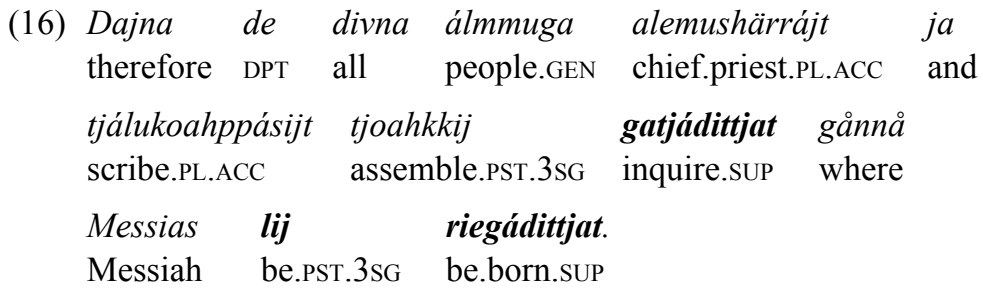

'Then he assembled all the chief priests and scribes of the people in order to inquire where the Christ was to be born.' ( $\AA \mathrm{T} 2000$ : Matthew 2:4)

In the above examples, the supine clauses headed by jámálguvádahtátjit 'in order to get into a trance' and gatjádittjat 'in order to inquire' optionally describe the purpose of the acts of 'using a shaman's drum' and 'assembling all the chief priests and scribes' expressed by the main clauses. However, the supines sjattatjit 'become' and riegádittjat 'be born' are connected with the copular verb that functions as the auxiliary verb of periphrastic predicates. As these kinds of periphrastic verb forms - hereafter referred to as the "supine construction" - have not 
been described on their own terms in previous accounts of the language, it is instructive to look at a variety of examples in order to understand the true nature of the phenomenon - not least because of the fact that similar formations seem to be altogether absent in the rest of the Saami languages:

(17) Ijáv la má de ládditjit, night.ACC be.PRS.2SG DPT DPT pick.cloudberries.SUP dån gut la getjo biejvev oadám? 2SG who be.PRs.2SG whole day.ACC sleep.PST.PTCP

'Are you going to pick cloudberries at night, then, you who have slept all day?' (SIKOR)

(18) $\begin{array}{llllll}\text { Iv } & \boldsymbol{l a} & \text { má } & \text { mån } & \text { duv } & \text { gåttåtjit. } \\ \text { NEG.PRS.1SG } & \text { be.CNG } & \text { DPT } & \text { 1SG } & \text { 2SG.ACC } & \text { kill.suP }\end{array}$ 'No, I am not going to kill you.' (Pirak 1993 [1937]: 85)

(19)

$\begin{array}{llllll}\text { Já, mån } & \text { javlav, } & \text { iv } & \text { mån } & \text { dajt } & \text { ane. } \\ \text { yes } 1 \mathrm{SG} & \text { say.PRS.1SG } & \text { NEG.PRS.1SG } & \text { 1SG } & \text { it.PL.ACC } & \text { use.CNG } \\ \text { Vuobdátjit } & \text { lev } & \text { mån } & \text { dajt. } & & \\ \text { sell.suP } & \text { be.PRs.1SG } & \text { 1SG } & \text { it.PL.ACC } & & \end{array}$

'Sure, I said, I am not using them [= bear spears]. I am going to sell them.' (Čállagat V: 16)

(20) Suohtas, javllá akta mánná, guhti le fun say.PRs.3sg one child who be.PRs.3SG ehpalgáhkov båråtjit ja sáftav jugátjit badjen, gå apple.cake.ACC eat.suP and juice.ACC drink.suP upstairs when 45 minuhta geldulasj vájaldibme sáme dájddavaráldin 45 minute.GEN exciting tour Saami art.world.INE le nåhkåm. be.PRS.3SG end.PST.PTCP 'It was fun, says one of the children who is going to eat apple cake and drink juice upstairs, as the exciting 45-minute tour through the world of Saami art has ended.' (SIKOR) 
Again, none of the above supines describe purposes or intentions of being per se; instead, they are best understood as periphrastic predicates. As such, they are structurally analogous to the so-called perfect tense with the identical auxiliary accompanied by the lexical verbs in the past participle, as seen in la (...) oadám 'you have slept' (17) and le nåhkåm '(the art tour) has ended' (20). What is more, they also appear to be semantically analogous to the perfect: whereas the perfect tense/aspect forms refer to actions and events that have occurred prior to the reference time, the supine construction refers to actions and events - such as berry-picking (17), (not) killing a bear (18), selling bear spears (19) or eating apple cake and drinking juice (20) - that will occur after the given reference time. Further, just as the Lule Saami perfect tense has a past equivalent in the past perfect (pluperfect) headed by the auxiliary in the past tense, the auxiliary of the supine may occur in the past as well (cf. already Examples 15-16 above):

$\begin{array}{llllll}J a & \text { de } & \text { bådij } & \text { biejvve } & \text { gå } & \text { Guossaluoktaj } \\ \text { and } & \text { DPT } & \text { come.PST.3sG } & \text { day } & \text { when } & \text { Guossaluokta.ILL }\end{array}$

\section{lijma vuolgátjit.}

be.PST.3PL leave.SUP

'Then came the day when we were to leave for Guossaluokta.' (SIKOR)

(22) Mij lij så dal munji sjattatjit?

what be.PsT.3sg DPT now 1sG.ILL happen.suP

$\begin{array}{llll}\mathrm{Na}, & \text { tjálitjav } & \text { allåsij } & \text { idet. } \\ \text { well } & \text { write.Pot.1sG } & \text { entirely } & \text { tomorrow }\end{array}$

'What was going to happen to me now? Well, I'll write about the whole thing tomorrow.' (Sagor i nattmössan)

(23) Tjaktjaj lij skåvllåj álgátjit, valla ittjij

fall.ILL be.PST.3sg school.ILL begin.sup but NEG.PST.3sG

gåjt de sån máhte dárustit.

still DPT 3sG can.CNG speak.Norwegian.INF

'He was going to begin school in the fall, but he still didn't speak Norwegian yet.' (SIKOR)

What is the function of the copular supine construction, then? The brief statements in the school textbooks (Tuolja \& Kuoljok 1999: 150-151, Nystø 2000: 74) attempt to describe the supine here as a kind 
of purposive, and it is not easy to read most of the above examples without sensing reference to intentional actions. Nevertheless, while it may be possible to interpret many of the supine constructions as some kind of periphrastic predicates with a modal meaning of intention, the construction is also used in contexts where such interpretations would seem quite far-fetched. In (15), (16) and (22), the lexical verbs in the supine form are the non-volitional verbs sjattatjit 'become; happen' and riegádittjat 'be born', and in (15), it is quite impossible to regard the subject viessom 'life; living' as a volitional agent of "becoming". Even in (23), the main predicate does not refer to a conscious intention to begin school in the fall, but merely to a generally determined phase in a child's life. Example (24) is one more instance of the same kind; the supine and the entire construction are in the passive (from buoreduvvat 'be improved' $\leftarrow$ buoredit 'improve'), and no agents are mentioned:

\begin{tabular}{|c|c|c|c|c|}
\hline $\begin{array}{l}\text { Danen } \\
\text { therefore }\end{array}$ & $\begin{array}{l}\text { muhtem } \\
\text { some }\end{array}$ & $\begin{array}{l}\text { buodo } \\
\text { dam.PL }\end{array}$ & $\begin{array}{l}\boldsymbol{l i} \\
\text { be.PRS.3PL }\end{array}$ & $\begin{array}{l}\text { buoreduvátjit. } \\
\text { improve.PASS.SUP }\end{array}$ \\
\hline
\end{tabular}

Quite differently from the schoolbooks' (Tuolja \& Kuoljok 1999: 150-151, Nystø 2000: 74) scanty characterizations of the liehket and supine construction as expressing purpose or intention of "being", the term intention also plays a role in Dahl's (2000: 310) simplified diagnostics of FTR devices as consisting of "intention-based" and "prediction-based" future time reference. Dahl does not clearly differentiate between synchronic and diachronic perspectives on future time reference, but rather sees the purest examples of grammaticalized FTR devices as outcomes of originally intention-based future time expressions that have also acquired non-intentional, prediction-based functions. Consequently, "whether FTR is overtly and obligatorily marked in prediction-based sentences can be used as one of the major criteria for whether it is grammaticalized in a language or not". If the functions of the Lule Saami supine construction are roughly divided into intention-based and prediction-based future time reference, it appears that the majority of authentic occurrences can be seen as carrying the flavor of intention. Even without attempting to trace the ultimate origins of the construction, it seems obvious that a FTR device based on a purposive converb somehow originates in intention-based future time expressions, and its prediction-based meanings are diachronically secondary. However, from a synchronic perspective it is obvious that 
the construction is no longer the sum of its parts, but a grammaticalized FTR device of its own - in Dahl's terms "a general future marker", at least to some degree.

Being a grammatical device referring to future time does not mean that the device is a future tense proper, though. Instead, it appears that perhaps the best characterization for the construction under discussion might be prospective (or prospective aspect) - and past prospective in (15-16) and (21-23) - as understood by, e.g., Comrie (1976: 64): "a state [...] related to some subsequent situation, for instance where someone is in a state of being about to do something" (see also, e.g. Dahl 1985: 111-112, 189). When speakers of natural languages refer to natural actors, it is not uncommon for projected future states and events to be preceded by intentional human agents. However, Examples (15-16) and (22-24) evidence that intentionality is not necessarily a decisive factor when using the Lule Saami supine construction as a FTR device that may also be seen as a periphrastic prospective aspect. Dahl (2000: 319) has later distanced himself from the idea of a prospective aspect, as the "evidence for the existence of a such a gram-type as distinct from early futures in general is somewhat shaky", but it will be argued in the following section that even from a morphosyntactic perspective, the Lule Saami construction seems to be most at home among other aspectual periphrastic forms of the language.

\section{Discussion and further remarks}

\subsection{The three "futures" of Lule Saami}

The above sections have shortly described three formally distinct grammatical means for referring to future time in Lule Saami. While the distinction between past and present tenses is often considered relatively free from additional aspectual and modal nuances, future time reference often includes elements of uncertainty, possibility or necessity. Further, when speaking about the future, language users are often most interested in the near future and have their own intentions to affect future events. Lule Saami is no exception in this respect.

There is no indisputable future tense in Lule Saami. Rather, there are only two inflectional absolute tenses - the past and the present, although the latter would be better labeled as non-past (see (6) and (9) for the present tense with future time reference). Of the three more explicit FTR devices described in Sections 2, 3 and 4, only the infinitive headed 
by galggat 'shall; must; intend' has been labeled a future tense, but this tradition has continued from Halász (1881) and Wiklund (1891) up to today without giving due attention to the fact the future time reference is only one of the many interrelated functions of the modal verb galggat 'shall; must; intend'. In a way, it is certainly only a matter of taste and flexibility of concepts like tense and future if galggat in (1a) is regarded as a manifestation of a future tense comparable to the past and present tenses. However, in that case, the question remains as to why the potential mood (Section 3) and the auxiliary supine construction (Section 4) should not be regarded as future tenses as well.

It seems that virtually all instances of the supine construction seen in Section 4 could, in principle, be exchanged with galggat and the infinitive. However, instead of regarding both devices as future tenses, it appears more appropriate to characterize them as prospective aspects and as such more on a par with other periphrastic aspectual forms. To begin with, both devices are also used in past tense forms such as lij $V$-tjit [be.PsT.3sG V-suP] and galgaj $V$ - $t$ [shall.PST.3sG V-INF] 'was (going) to $V$ ', which makes them semantically analogous to not only the perfect and past perfect (pluperfect) but also the progressive and past progressive periphrastics that have received less attention in Saami linguistics (see, e.g., Spiik 1989: 105, 109). Based on Example (22) above, it is possible to present the following subset of aspectual periphrastic forms that are unusually symmetrical in both form and function:

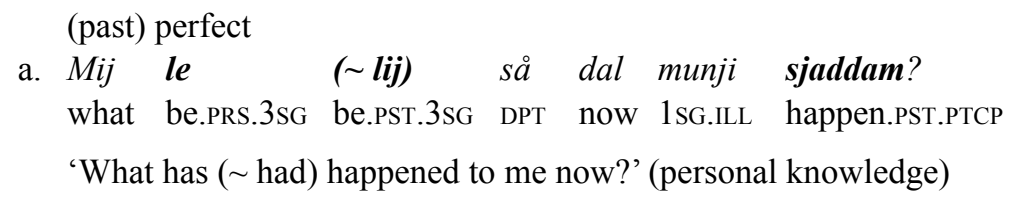
(past) progressive

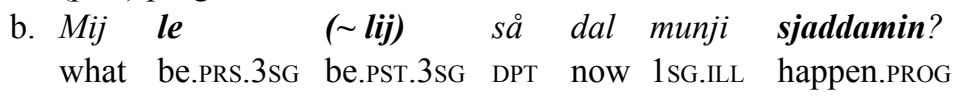
'What is ( was) happening to me now?' (personal knowledge) (past) prospective (cf. Example 22)

$\begin{array}{lllllll}\text { c. } & \text { Mij } & \text { le } & (\sim \text { lij }) & \text { sa } & \text { dal munji } & \text { sjattatjit? } \\ \text { what } & \text { be.PRS.3SG } & \text { be.PST.3SG } & \text { DPT } & \text { now } & 1 \mathrm{SG} . I L L & \text { happen.SUP }\end{array}$ 'What is ( was) going to happen to me now?' (personal knowledge) 
Unlike Dahl (2000: 319), I still find the notion of prospective aspect useful, as a characterization like this seems to be the most economical way to describe the Lule Saami supine construction as a grammaticalized yet largely optional periphrastic aspectual FTR device comparable to the perfects and progressives in the language. The same characterization seems to apply to the alleged galggat future as well, as it appears that $(25 \mathrm{c})$ is more or less synonymous with (25d) above:

\section{d. Mij galggá ( galgaj) så dal munji sjaddat? what shall.PRs.3sG shall.PST.3SG DPT now 1SG.ILL happen.INF}

'What is ( was) going to happen to me now?' (personal knowledge)

Space does not allow for a detailed comparison of the two devices, but it may be remarked that while the most recent Lule Saami translation of the New Testament ( $\AA \mathrm{T} 2000)$ contains 53 periphrastic supine constructions, none of them exist in the translation from 1903 ( $\AA \mathrm{T}$ 1903), which goes back to earlier Saami translations made by nonSaami Swedish clerics. The 2000 translation has been described as a deliberately puristic attempt to reduce the amount of Scandinavian interference in literary Lule Saami (Kuoljok 2002, 2004). None of the phenomena discussed here have been explicitly mentioned in connection with this, but it is remarkable that as many as 38 of the 53 supine constructions in $\AA \mathrm{T} 2000$ were preceded by the galggat construction as seen in (26), the predecessor of (16) seen above:

$$
\begin{aligned}
& \text { (...) ja sån kåtjoi kaikait pajemus prästait ja } \\
& \text { and 3sg order.PST.3sg all.PL.ACC high.SUPv priest.PL.ACC and } \\
& \text { tjalokåppasit almoka kaskan tjåkkai ja katjati } \\
& \text { scribe.PL.ACC people.GEN among together and inquire.PST.3SG } \\
& \text { siast, kånne Kristus kalkai riekatit. } \\
& \text { 3PL.ELA where Christ shall.PST.3Sg be.born.INF } \\
& \text { '(...) and he assembled all the chief priests and scribes of the people, } \\
& \text { and inquired where the Christ was to be born.' ( } \AA \text { T 1903: Matthew 2:4) }
\end{aligned}
$$

Even in the purified language of the most recent translation of the New Testament, galggat futures à la galgaj riegadit 'was to be born' (the current spelling of kalkai riekatit in (26)) are fully possible. However, the "new" supine construction seems to have a relatively long and established past, as the construction is used in texts produced in various dialect areas from Jåhkåmåhkke (Sweden) to Divtasvuodna 
(Norway), and it can already be found in Anta Pirak's (1873-1951) classical work Jåhtte sáme viessom (Jåhttee saamee viessoom) from 1937 (see Example (18) above). On the other hand, the earliest documented texts in Lule Saami (Halász 1885, Qvigstad 1929) do not contain the construction in question.

The potential mood, in turn, seems to lack a direct relation to the aspectual periphrastic forms discussed above. Further, the potential is the only one of the three FTR devices that is a synthetic inflectional category in itself, and as the potential lacks past tense forms, the entire category could be seen on a par with the indicative past and present tenses. It was remarked above (see Table 1 in Section 3) that the potential is in paradigmatic contrast - and quite symmetrically so (see also Table 2) - with the present and past indicative, and from this perspective it would not be an inconceivable idea to reappraise the so-called potential as a kind of tense. However, the forms in question cannot be regarded as an absolute future tense, as they may refer to present time as well: jutsátji [make.noise.Рот.3PL] 'they are probably making noise' in (4) is, in accordance with its label, a potential mood that presents the state of affairs as possible but not certain. On the other hand, it could be possible to interpret potential forms like this as something similar to the German future auxiliary werden 'will', which can also refer to present time while carrying a suppositional reading, as in sie werden Lärm machen 'they will make noise; they are probably making noise'. ${ }^{8}$

But then again, Examples (5-10) show many occurrences of the so-called potential mood in which there seem to be almost no traces of uncertainty, and the main feature differentiating the potential from the present indicative is that the latter does not primarily refer to future events or states. The observations above are not presented in order to refute the traditional view of the potential as a mood, but rather to provide a more accurate picture of the verb forms that deserve our attention also as an inflectional category that comes close to the idea of a future tense. Moreover, it appears that especially the Lule Saami potential forms deserve to be mentioned as an FTR device that lacks obvious parallels in other Saami languages, whereas as the cognates of the alleged galggat future have similar functions in the neighboring sister languages as well (Section 2).

The concept of the "future tense in Lule Saami" is not fundamentally different from that of many other languages of Europe. As regards the

8 I would like to thank an anonymous reviewer for this observation. 
language of the present article, English has multiple FTR devices such as the auxiliaries will and shall, as well as the so-called going-to future and the be + to construction. While will and shall are often alternatively regarded as modal verbs, the true nature of the going-to (or gonna) future is even more debated, and interpretations of the be + to construction vary from "an idiom expressing futurity, with varied connotations of 'compulsion', 'plan', 'destiny', etc, according to context" (Quirk et al. 1985: 143) to the opposite, a modal expression "with a connotation of expected posterior actualization of the situation indicated by the infinitive clause" (Declerck 2010: 281). In actual usage, the abovementioned FTR devices are largely interchangeable, and the same seems to apply to the Lule Saami expressions. In a nutshell, it appears that the FTR functions of the galggat construction (Section 2) and the supine construction (Section 4) can be compared with those of the going-to future in English with which the examples have been usually translated (although other alternatives exist as well). On the other hand, FTR functions of the potential (Section 3) are more like those of the auxiliaries will and shall. In Dahl's (2000) terms, the former types are predominantly examples of intention-based futures, whereas the latter are better representatives of prediction-based futures. Compare the two types in (22) repeated here:

$\begin{array}{llllll}\text { Mij } & \text { lij } & \text { så } & \text { dal } & \text { munji } & \text { sjattatjit? } \\ \text { what } & \text { be.PST.3SG } & \text { DPT } & \text { now } & \text { 1SG.ILL } & \text { happen.sUP } \\ \mathrm{Na} & \text { tjálitjav } & \text { ållåsij } & \text { idet. } & \\ \text { well } & \text { write.POT.1SG } & \text { entirely } & \text { tomorrow }\end{array}$

'What was going to happen to me now? Well, I'll write about the whole thing tomorrow.' (Sagor i nattmössan)

From a purely morphosyntactic perspective, the major finding of the above sections is the mere existence of the periphrastic prospective consisting of the copula and the supine. Further, unlike the multifaceted semantics of the modal verb galggat (Section 2) and the potential (Section 3), the supine construction in question seems to have quite clear borders: while the exact semantics and possible modal shades of individual sentences may vary, the core meaning of the construction is a future-like prospective aspect and it can hardly be confused with 
other, purposive converbal functions of the supine. ${ }^{9}$ The function of the construction is more than the sum of its parts: the prospective aspect is not automatically brought forth by the purposive converb, to say nothing of assigning the aspectual meaning to the copula any more than in the formally analogous perfects and progressives seen in (25a-b) above (see also Section 5.3 below). ${ }^{10}$

\subsection{A Finnish parallel to the Lule Saami prospective supine construction}

Before focusing on the typological and areal implications of the Lule Saami FTR devices, the description of the Lule Saami supine in a prospective aspect calls for a particular digression to an interesting parallel in Finnish. As explicitly pointed out by Korhonen (1981: 298), the Saami supine is semantically quite similar to the Finnish purposive converb in -takse- (the converb marker is always followed by a possessive suffix). However, the same non-finite also has other functions in addition to the predominantly purposive use. With respect to the long history of Finnish linguistics, such functions have received surprisingly little attention and next to no empirical studies. One of the most neglected constructions has been termed the "fatum construction" (Latin for 'destiny; fate'). Without going into the relatively few details of the research history, it suffices to state that the construction is regularly dismissed as something that occurs in repetitive temporal and conditional clauses and can be characterized as an "only partly productive" means to express that the state of affairs is not under control (see, e.g., Saukkonen 1965: 171, Ikola 1974: 65-66, and Hakulinen et al. 2004: 446). However, while it is true that a major bulk of the fatum constructions do occur in repetitive subordinate clauses like (27), it is possible

9 For the record, it may be added that in addition to the purposive and future functions of the supine, it is possible to discern a third main function in which the Lule Saami supine modifies predicative adjectives such as in the phrases jåhtel/valle viegatjit [fast run.sup] 'able to run fast; fast runner', gárves vuolgátjit [ready leave.sup] 'ready to go' and tjiehppe tjálátjit ja ságastittjat 'skilled in writing and discussing', as in (iii):
(iii) Sån lij tjiehppe tjálátjit ja ságastittjat.
3sg be.PST.3sg skilled write.suP and discuss.suP
'S/he was skilled in writing and discussing.' (SIKOR)

10 True, the existence of liehket 'be' plus the supine is already recorded in Tuolja and Kuoljok (1999) and Nystø (2000), but the school textbooks may be partly excused for the impromptu decision to lump the aspectual construction in with the converbal functions of the supine. 
to come across authentic occurrences of a similar construction as main predicates of various kinds $(28-33)$ :

Finnish

(27) Suutu

get.angry.IMP.2SG DPT just if $(2 \mathrm{sG})$ be.PRS.2sG

suuttuaksesi!

get.angry.PURP.2SG

'Feel free to get angry, if you must.' (Ikola 1974: 65)

(28) Millainen=han soppa tästä vielä on what.kind=I.wonder mess this.ELA still be.PRs.3sG

syntyäkseen?

be.born.PURP.3SG

'I wonder what kind of mess this is going to become.' (CSC)

(29) Aika näyttää, mitä kaikkea tässä vielä time show.PRS.3SG what.PART everything.PART here still on tapahtuakseen.

be.PRS.3SG happen.PURP.3SG

'Time will show what will still happen.' (CSC)

(30) Ainakin minun kohdalla se tuskin on at.least 1SG.GEN as.regards it hardly be.PRS.3SG

toimiakseen.

function.PURP.3SG

'At least for my part, it [= a love relationship] will hardly work.' (CSC)

(31) Eli kyllä ne kuukautiset on tullakseen in.other.words DPT it.PL menstruation be.PRS.3SG come.PURP.3SG ainakin jossakin vaiheessa:) at.least some.INE stage.INE

'In other words, the period will come back [after giving birth] at some stage, at least.' (CSC) 


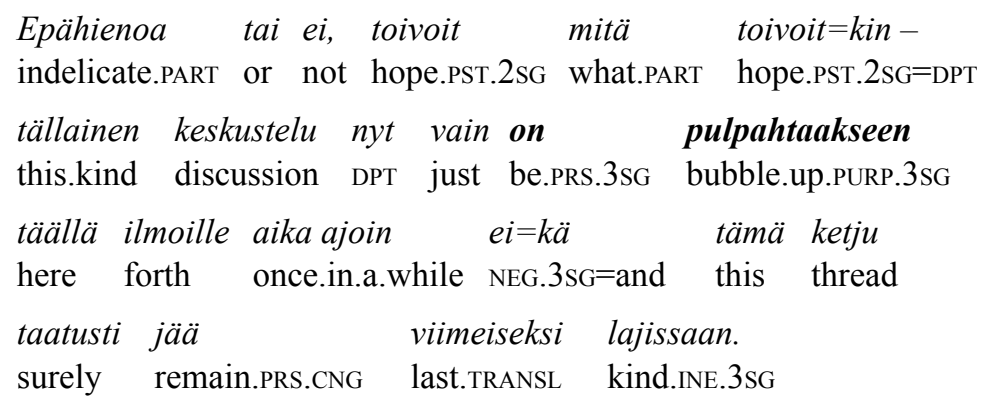

'Indelicate or not, whatever you were hoping for - a discussion like this just will pop up here every now and then, and this thread will surely not be the last of its kind.' (CSC)

(33)

Perheen pienimmäinen kuitenkin oli syntyäkseen family.GEN smallest.one in.any.case be.PST.3sg be.born.PURP.3sg jo pari kuukautta etuajassa. -Eikä already couple month.PART ahead.of.time NEG.3SG=and sitten kuitenkaan syntynyt. then after.all be.born.PST.CNG

'The youngest one in the family was going to be born as early as two months premature. - But was not born at that time after all.'

(Kotiseutu-uutiset 19.1.2012)

True, independent fatum constructions like the ones seen in (28-33) are quite infrequent in the language and are best found in large corpora of colloquial internet discussions, but this does not diminish the fact they are regarded as unproblematic by many speakers even though such examples seem to have never been presented in linguistic literature. ${ }^{11}$

To return to the Lule Saami prospective aspect described above, it can be articulated that the above Finnish construction is structurally as identical as it can be to the one in Lule Saami: the periphrastic verb construction is composed of the auxiliary copula olla 'be' followed by the lexical verb in the converb form whose primary function is purposive 'in order to V'. Quite like the Lule Saami supine, the Finnish converb has lost its primary meaning, and olla 'be' plus the converb in

11 The reason for briskly presenting as many as six examples of independent fatum constructions here is that, surprisingly enough, none like these have apparently ever been presented in the long history of Finnish linguistics, where it has been instead claimed that the fatum construction occurs virtually only in repetitive conditional and temporal clauses (27). 
-takse- must be regarded as a kind of periphrastic verb form. As seen in the translations of the examples, the closest English equivalents of the construction seem to be the will and going-to futures. It is not possible to scrutinize all possible meanings and implications of the Finnish construction within the confines of the present paper, but it seems that the label "fatum construction" is, in a way, quite informative: Almost all of the lexical verbs are more or less inactive in nature, and the overall contexts of the fatum constructions do carry a flavor of fate or destiny as regards the future. To a certain degree, this seems to apply to many non-intentional future usages of the Lule Saami supine construction as well (see Section 4).

On the other hand, (33) shows that the Finnish construction is reminiscent of Lule Saami also in that the auxiliary may occur in the past tense, which makes the entire construction look more like an aspectual periphrastic rather than a tense category. (The continuation in (33) shows that the "fate" in question may turn out to be untrue.) In fact, it is even possible to present a tripartite subset of aspectual periphrastic forms akin to the ones presented for Lule Saami in $(25 \mathrm{a}-\mathrm{c})$ above:
a. Millainen=han soppa tästä on syntynyt? what.kind=I.wonder mess this.ELA be.PRS.3SG be.born.PST.PTCP 'I wonder what kind of mess this has become.' (personal knowledge)
b. Millainen=han soppa tästä on syntymässä? what.kind=I.wonder mess this.ELA be.PRS.3sG be.born.PROG 'I wonder what kind of mess this is becoming.' (personal knowledge)
c. Millainen=han soppa tästä on syntyäkseen? what.kind=I.wonder mess this.ELA be.PRS. $3 \mathrm{SG}$ be.born.PURP. $3 \mathrm{SG}$ 'I wonder what kind of mess this is going to become.' (personal knowledge)

It is not possible to delve deeper into the history and origins of the Finnish construction in the present paper, and more synchronic research is also needed in order to better understand the various modal connotations and general acceptability of different types of the fatum construction among Finnish speakers. It may be added that due to the marginality of the specialized prospective construction presented here in $(34 \mathrm{c})$, the Finnish progressive construction in (34b) seems to have a wider semantic scope than that of Lule Saami (25b) (cf. Niva 2015). It appears that some of the prospective constructions in (28-33) can be replaced 
with the progressive without any obvious change in meaning. It may also be specified that the Lule Saami supine does not appear to be used in functions analogous to those of the reduplicative fatum construction in Finnish (27). It is possible that the relatively high frequency of fatum constructions in comparison to the prospective constructions exemplified by (28-33) has partly prevented the construction from acquiring a less "destinative" usage.

It might be too daring to try to describe the Finnish and Lule Saami constructions as having common origins (but see, e.g., Itkonen 1938 for another periphrastic construction), but it is astonishing to see that the two neighboring languages - traditionally meeting each other in the Jiellevárre/Jällivaara (Gällivare) municipality in the Norrbotten County of Sweden - have structurally identical grammatical means to refer to a "destinative future" or to express prospective aspect, although they consist of materially unrelated morphemes and both phenomena have remained undescribed before the present study.

\subsection{Typological and areal perspectives}

As has been repeated above, there is no indisputable future tense in Lule Saami. Instead, in addition to the non-past "present" tense, there are at least three grammaticalized FTR devices that also carry various modal and aspectual meanings commonly related to future time reference. These facts fit together with Dahl's (2000) findings in his paper "The grammar of future time reference in European languages", in which he gives special attention to what he calls a "futureless" area in Northern Europe which includes at least all Finno-Ugrian and Germanic languages except English" (Dahl 2000: 325-326). While it must be added that Dahl and Velupillai (2005) have later rightfully acknowledged the existence of morphological futures in Udmurt and Tundra Nenets, it is true that obligatory FTR marking in what Dahl calls "prediction-based contexts" (in contrast to intention-based, prototypically human-controlled contexts) is quite uncommon in the Uralic and Scandinavian languages of Northern Europe. It would thus be quite surprising to find an inflectional future tense marker in Lule Saami, but the so-called potential mood marker would nevertheless make a rather good candidate in some contexts (see Section 3).

In spite of the scarcity of indisputable future tenses in Northern Europe and elsewhere in Europe, Dahl (2000: 317-325) presents a survey of the "future gram families" in languages spoken in Europe. 
On the basis of dozens of European languages, Dahl describes fourteen major and three minor types of FTR devices according to their etymological origins, often based on different kinds of auxiliaries such as "de-andative constructions" like be going to, the Germanic de-obligative construction (English shall, Norwegian skal, Swedish ska(ll), etc.), the North European de-volitive construction à la will, and de-venitive constructions such as Swedish kommer att ("comes to"). The Lule Saami galggat future undoubtedly belongs to the "Germanic" de-obligative type (Section 2), but Dahl's inventory of future gram families lacks clear parallels to the use of the Lule Saami potential and supine as FTR devices. Apparently the closest equivalent to the supine construction (Section 4) is the type labeled as "Slavic copular constructions" that include "imperfective futures formed with the stem bod-/ bud-and an $l$-participle or infinitive in North (West and East) Slavic" (Dahl 2000: 324). Indeed, keeping in mind that the Lule Saami supine is mostly used in contexts in which Slavic and many other European languages employ their infinitives (Haspelmath 1989), Russian futures such as (35-36) come structurally quite close to those seen in Section 4:

\begin{tabular}{lllll}
\multicolumn{2}{l}{ Russian } & & \\
(35) $Я$ не & будy & убивать & тебя. (cf. Example 18) \\
Ja ne & budu & ubivat' & tebja. \\
1SG & NEG & be.FUT.1SG & kill.INF & 2SG.ACC \\
'I am not going to kill you.' (personal knowledge)
\end{tabular}
(36) Я буду продавать их. (cf. Example 19)
Ja budu prodavat' $i x$.
$1 \mathrm{sg}$ be.FUT.1SG sell.INF it.PL.ACC

'I am going to sell them.' (personal knowledge)

Interestingly, the Russian future construction has occasionally been compared with Uralic FTR devices. Scholars like Genetz (1881: 220) and Metslang (1996: 135-136) have referred to expressions like lienet istumah 'you will sit' (37) in Karelian and other minor Finnic vernaculars:

\footnotetext{
Karelian

(37) lienet

'You will be sitting under a woman's buttocks.' (Genetz 1881: 5-6)
} 
Finnic and especially Livonian FTR devices have been recently discussed by Norvik (2013, 2015), but Metslang (1996: 136-139) also goes on to refer to Mari, Permic and Hungarian as preservers of the Uralic (Finno-Ugric) suppletive future copula *le- whose descendants have allegedly remained as carriers of modal and future meanings. According to Metslang, the development of *le- and its analogues in Slavic "could hardly take place in each language separately" but are rather results of language contacts. ${ }^{12}$ The verb form lienet in the oft-cited Example (37) is usually considered a suppletive potential form of the copula in Finnic linguistics, but in Karelian, the verb lie(nöy) often functions as a future copula also without an infinitival lexical verb (KKS s.v.; see also Saukkonen 1965: 176-179 for Finnic in general). The Lule Saami copula liehket undoubtedly descends from the ancient "future copula" just mentioned. However, Metslang's argumentation does not account for the fact that Lule Saami liehket and its cognates elsewhere in Saami are the unmarked default copulas of the branch and are consequently inflected for the past tense as well.

While the Russian and Finnic future copulas accompanied by infinitival main verbs look quite similar indeed, the Lule Saami supine construction as a FTR device is, after all, fundamentally different in that the auxiliary verb does not carry a future meaning in itself. Rather, both the Lule Saami supine construction (Section 4) and its structural parallel in the Finnish fatum construction (Section 5.3) must be kept separate from the aforementioned FTR devices, as both of them consist of the ordinary copulas and the purposive converbs of the two languages. Perhaps the closest typological parallel of these constructions is found in Kolyma Yukaghir, where a non-finite likewise labeled as supine is used as both a purposive converb and an infinitival complement, but also - when combined with the auxiliary l'e- 'be' - to form a so-called periphrastic prospective that is said to express relative immediate future:

Kolyma Yukaghir

$\begin{array}{llll}\text { čarčaqan d'e } & \text { tet-ul lek-tin l'e-je } \\ \text { C. } & \text { DPT } & \text { you-ACC } & \text { eat-SUP be-INTR.1SG }\end{array}$

'Charchahan, I am going to eat you.' (Maslova 2003: 179)

12 As for Mari, Permic and Hungarian, Metslang speaks about the future copulas only, not about periphrastic FTR devices involving other verbs. 
Otherwise, Schmidtke-Bode (2009: 178-185) describes future constructions originating in purposives as developing from expressions of motion-cum-purpose (such as going to) in particular; see also Grossman and Polis (2014: 36-38) for discussion of semantically reminiscent examples from other language families.

Also the FTR use of the Lule Saami potential mood provides an addition to Dahl's (2000) typology of European future markers. Incidentally, it is worth noting that even though Dahl's de-venitive future type occurs in not only Scandinavian (kommer att V) and Finnish (tulee V-maan), as well as elsewhere in Finnic (Saukkonen 1965: 151, Metslang 1996: 130-133, and Dahl 2000: 320), but also in North Saami (boahtá V-t; Sammallahti 2005: 137, 147, 287), Lule Saami shows little signs of having adopted an analogous Scandinavism. The reasons for this cannot lie in the lack of Scandinavian contacts, but rather in the fact that Lule Saami already has enough well-established FTR devices.

Finally, even though the aim of the present paper is not to contribute to the Proto-Saami-level reconstruction of the potential and supine morphemes, it is worth noting that it has been suggested that the ProtoSaami supine marker may originate in the infinitive form of the potential stem (Korhonen 1981: 298). However, the idea of an infinitive form of a mood stem sounds quite anomalous - especially as the infinitive marker itself is considered to originate from a verbal noun in a directional case. As often is the case in classical Uralic historical morphology, no functional arguments in support of a typologically unparalleled conjecture have been presented either. More research is needed, and Halász's (1881: 60) early proposal about a derivational suffix may need to be reconsidered.

\section{Conclusion}

The above sections have discussed three FTR devices in Lule Saami and one in Finnish. Of these, only the Lule Saami modal galggat 'shall; must; intend' has been characterized as a future marker in earlier descriptions of the language, but examples of the usage of the so-called potential mood as well as the supine with the auxiliary liehket 'be' show that galggat is by no means the only grammaticalized FTR device in Lule Saami. Moreover, while the galggat future has functionally similar cognates in other Saami languages and the entire phenomenon is evidently related to the skal/ska(ll) future in Scandinavian - the very 
galggat being a distant relative of the Germanic verb - it seems that the potential mood and especially the supine construction are used as FTR devices exclusively in Lule Saami and not in the neighboring North and Pite Saami. However, the Lule Saami supine construction is interestingly similar to some of the heretofore ignored functions of the so-called fatum construction in Finnish. Finally, it must be remembered that the indicative present tense can also be used to refer to future time and it would therefore be more exact to characterize the category as non-past.

The concept of a future tense is notoriously difficult and controversial, as expressions of future events and actions are often accompanied by modal tones, not least because of the fact that grammaticalized FTR devices often originate in modal expressions. However, by examining various kinds of authentic occurrences of the FTR devices discussed it is possible to observe that they are also used in contexts where additional modal meanings must be excluded. For example, the predominantly (and apparently originally) intention-based supine construction turns out to be used in prediction-based contexts as well, and is therefore a better candidate for being regarded as a true, less ambiguous FTR marker. On the other hand, it seems that the construction as a whole is best defined as an aspectual category (prospective) on a par with periphrastic perfects and progressives.

New observations such as the ones presented in the preceding sections often tempt us to reconsider and revise labels used in earlier descriptions of individual languages. The Lule Saami potential is not merely a mood of potentiality, and the purposive converbs in Lule Saami and Finnish are not simply purposive converbs - free adverbial verb forms denoting purpose - and at least in Finnish, the verb form conveniently labeled as progressive ("the third or MA infinitive inessive" in the Finnish grammatical tradition) is more than a progressive: all these categories can also be used as FTR devices. However, in my opinion, it is of secondary importance to continuously revise grammatical labels in search of perfect terminology. It is more important to understand that the functions of the forms and constructions discussed above are much more multifaceted than what their labels may suggest at first glance.

The Saami languages are quite seldom represented in typological studies, and even in areal-typological surveys of phenomena like future time reference in Europe or in Uralic, the Saami languages may be altogether absent (Dahl 2000) or, at best, they are represented by haphazard examples from North Saami and only occasionally from other Saami 
languages, if the internal variation of the branch is acknowledged at all (Metslang 1996: 134, 136, 138). It is to be hoped that the findings of the present paper prove that individual Saami languages must be understood and described on their own premises, and are in that way able to provide Uralists and other linguists with important and novel information about phenomena that are foreign to even their closest sister languages. In the same vein, it may sometimes be important to cut loose from traditional pan-Saami concepts like the potential mood that is characterized as a mood that indicates events and actions as probable or possible, but uncertain: The Lule Saami potential comes at times close to resembling a future tense that refers to future states of affairs that may be considered as true and certain as future events may be. The short digression to the Finnish analogue of the Lule Saami supine construction shows that neither of them must be dismissed as occasional quirks of a lesser-known language or only marginal phenomenon in a better-known language, but a combination of a copula and a purposive converb may be a cross-linguistically relevant source of future time reference devices.

\author{
Address: \\ Jussi Ylikoski \\ Department of Language and Culture \\ UiT The Arctic University of Norway \\ PO Box 6050 Langnes \\ NO-9037 TROMSØ \\ E-mail: jussi.ylikoski@uit.no
}

\begin{abstract}
Abbreviations
ACC - accusative, ADV - adverb, CMPV - comparative, CNG - connegative, COM - comitative, DPT - discourse particle, DU - dual, ELA - elative, GA - genitive-accusative, GEN - genitive, ILL - illative, IMP - imperative, INE - inessive, INF - infinitive, INTR - intransitive, LOC - locative, NEG negative, PART - partitive, PASS - passive, PL - plural, POT - potential, PROG - progressive, PRS - present, PST - past, PTCP - participle, PURP purposive, $\mathrm{Q}$ - question, REFL - reflexive, SG - singular, SUP - supine, SUPV - superlative, TRANSL - translative
\end{abstract}




\section{References}

Aikio, Ante (2009) The structure of North Saami. Course handout. Salt Lake City: The University of Utah, Department of Linguistics.

Andersen, Kurt Tore (2002a) Gå skirri sádá. Divtasvuodna: Báhko.

Andersen, Kurt Tore (2002b) Iednegiella 8. Indre Billefjord: Iđut.

Andersen, Kurt Tore (2004) Iednegiella 9. Indre Billefjord: Iđut.

ÅT 1903 = Atå Testamenta jårkålum tan taro-kielak Atå Testamenta milte, mi lä Kånåkasast nanostum jaken 1883. Stockholm: P. Palmquist.

ÅT $2000=$ Ådå Testamennta. Uppsala: Svieriga rámátsiebrre 2000.

Bartens, Hans-Hermann (1980) Die Verwendung von Potential und Konditional im Lappischen. Helsinki: Finnisch-Ugrische Gesellschaft.

Bartens, Hans-Hermann (1986) "Die Stellung der Supinumformen im lappischen Sprachsystem”. In Wolfgang Veenker. Festschrift für István Futaky. FinnischUgrische Mitteilungen 10, 17-40.

Č́llagat V. Kárášjåkka: Sámi gir'jilav' digåd' di 1976.

Comrie, Bernard (1976) Aspect. An introduction to the study of verbal aspect and related problems. Cambridge: Cambridge University Press.

$\mathrm{CSC}=$ CSC - IT Center for Science: Language Bank of Finland. The Suomi24 subcorpus. Available online at $<$ https://korp.csc.fi/?prequery_within=sentence\&cq $\mathrm{p}=\% 5 \mathrm{~B} \% 5 \mathrm{D} \& \mathrm{corpus}=\mathrm{s} 24$ _001,s24_002,s24_003,s24_004,s24_005,s24_006,s24_ 007,s24_008,s24_009>. Accessed on 30.06.2016.

Dahl, Östen (2000) “The grammar of future time reference in European languages". In Östen Dahl. Tense and aspect in the languages of Europe, 309-329. Berlin and New York: Mouton de Gruyter.

Dahl, Östen and Viveka Velupillai (2005) "The future tense". In Bernard Comrie, Matthew Dryer, David Gil, and Martin Haspelmath. World atlas of language structures, 270, 278-279. Oxford: Oxford University Press.

Declerck, Renaat (2010) "Future time reference expressed by be to in Present-day English". English Language and Linguistics 14, 271-291.

Faarlund, Jan Terje, Svein Lie, and Kjell Ivar Vannebo (1997) Norsk referansegrammatikk. Oslo: Universitetsforlaget.

Genetz, Arvid (1881) "Venäjän Karjalan kielestä. Kielennäytteitä, sanakirja ja kielioppi”. Suomi II, 14, 1-248.

Grossman, Eitan and Stéphane Polis (2014) "On the pragmatics of subjectification: The grammaticalization of verbless allative futures (with a case study in Ancient Egyptian)". Acta Linguistica Hafniensia 46, 25-63.

Hakulinen, Auli, Maria Vilkuna, Riitta Korhonen, Vesa Koivisto, Tarja Riitta Heinonen, and Irja Alho (2004) Iso suomen kielioppi. Helsinki: Suomalaisen Kirjallisuuden Seura.

Halász, Ignácz (1881) Svéd-lapp nyelvtan és olvasmányok. Budapest: Magyar Tudományos Akadémia. 
Halász, Ignácz (1885) Svéd lapp nyelv. I. Lule- és Pite lappmarki nyelvmutatványok és szótár. Budapest: Magyar Tudományos Akadémia.

Haspelmath, Martin (1989) "From purposive to infinitive - a universal path of grammaticalization". Folia Linguistica Historica 10, 287-310.

Ikola, Osmo (1974) Lauseenvastikeoppia. Nykysuomen lauseenvastikkeiden ja niihin verrattavien rakenteiden selvittelyä. Helsinki: Suomalaisen Kirjallisuuden Seura.

Itkonen, Erkki (1938) "Satakuntalaista lainaperua ruotsinlapin syntaksissa". Virittäjä 42, 321-325.

KKS = Virtaranta, Pertti and Raija Koponen (1968-2005) Karjalan kielen sanakirja . Helsinki: Suomalais-Ugrilainen Seura - Kotimaisten kielten tutkimuskeskus.

Koivulehto, Jorma (2001) "The earliest contacts between Indo-European and Uralic speakers in the light of lexical loans". In Christian Carpelan, Asko Parpola, and Petteri Koskikallio. Early contacts between Uralic and Indo-European: Linguistic and archaeological considerations, 235-263. Helsinki: Finno-Ugrian Society.

Korhonen, Mikko (1974) Die Konjugation im Lappischen. Morphologisch-historische Untersuchung. II. Die nominalen Formkategorien. Helsinki: Suomalais-Ugrilainen Seura.

Korhonen, Mikko (1981) Johdatus lapin kielen historiaan. Helsinki: Suomalaisen Kirjallisuuden Seura.

Koskinen, Arja (1998) Toiminnan välttämättömyys ja mahdollisuus. Pohjoissaamen modaalisten ilmausten semantiikkaa ja syntaksia. Helsinki: Suomalais-Ugrilainen Seura.

Kotiseutu-uutiset $=$ "Vauva laittaa arjen uuteen järjestykseen". Kotiseutu-uutiset 19.1.2012. Available online at < http://kotiseutu-uutiset.com/uutiset/2012/01/19/ vauva-laittaa-arjen-uuteen-jarjestykseen/> . Accessed on 30.06.2016.

Kuoljok, Susanna Angéus (2002) "Giella Ådå Testamenta ådå jårggålimen”. Sámi dieđalaš áigečála 2002, 1, 12-18.

Kuoljok, Susanna Angéus (2004) “Ådå Testamennta ådåsis”. Sámi dieđalaš áigečála 2004, 1, 32-42.

Lehtiranta, Juhani (1992) Arjeploginsaamen äänne- ja taivutusopin pääpiirteet. Helsinki: Suomalais-Ugrilainen Seura.

Majtinskaja, Klara E. (1973) "Buduščee vremja v finno-ugorskix jazykax". Sovetskoe Finno-Ugrovedenie 9, 2, 81-90.

Maslova, Elena (2003) A grammar of Kolyma Yukaghir. Berlin and New York: Mouton de Gruyter.

Metslang, Helle (1996) "The development of the futures in the Finno-Ugric languages". In Mati Erelt. Estonian: Typological studies I, 123-144. Tartu: University of Tartu.

Niva, Heidi (2015) Olen lentämässä todennäköisesti Chileen. OLLA + V-mAssA ja $O L L A+\mathrm{N}-s S A$ intentioiden ja tulevan ilmaisemisessa. Master's Thesis. Helsinki: Helsingin yliopisto. Suomen kielen, suomalais-ugrilaisten ja pohjoismaisten kielten ja kirjallisuuksien laitos. Available online at $<$ https://helda.helsinki.fi/ handle/10138/157413>. Accessed on 21.10.2016.

Norvik, Miina (2013) "Future time reference in the Finnic languages: LEE(NE) -verbs". Journal de la Société Finno-Ougrienne 94, 125-164. 
Norvik, Miina (2015) Future time reference devices in Livonian in a Finnic context. Tartu: University of Tartu Press.

Nystø, Anders (2000) Sámásta 1. Vuostasj girjje 1. Julevsáme giellakurssa. Julevsámegiella álggijda. Divtasvuodna: Báhko.

Persen, Åge (1999a) Bov låhkå biejvijt ja vahkojt. Julevsábmáj: Samuel Gælok. Indre Billefjord: Iđut.

Persen, Åge (1999b) Bov lohká beivviid ja vahkuid. Indre Billefjord: Iđut.

Pirak, Anta (1993) [1937] Jåhtte sáme viessom. Kristiansund: Th. Blaasvær.

Quirk, Randolph, Sidney Greenbaum, Geoffrey Leech, and Jan Svartvik (1985) A Comprehensive grammar of the English language. London: Longman.

Qvigstad, J. (ed.) (1929) Lappiske eventyr og sagn. IV. Lappiske eventyr og sagn fra Lyngen II og fra Nordland. Oslo: Aschehoug.

Rydving, Håkan (2013) Words and varieties. Lexical variation in Saami. Helsinki: Finno-Ugrian Society.

Sagor i nattmössan (s.a.) = Sagor i nattmössan - lulesamiska. Available online at $<$ http: $/ /$ urskola.se/layout/set/print/Produkter/171130-Sagor-i-nattmossan-lulesamiskaDen-elaka-giraffen-del-1>. Accessed on 30.06.2016.

Sammallahti, Pekka (1998) The Saami languages. An introduction. Kárášjohka: Davvi Girji.

Sammallahti, Pekka (2005) Láidehus sámegiela cealkkaoahpa dutkamii. Kárášjohka: Davvi Girji.

Saukkonen, Pauli (1965) Itämerensuomalaisten kielten tulosijainfinitivirakenteiden historiaa. I. Johdanto. Adverbaali infinitiviv. Helsinki: Suomalais-Ugrilainen Seura.

Schmidtke-Bode, Karsten (2009). A Typology of Purpose Clauses. Amsterdam and Philadelphia: John Benjamins.

SIKOR $=$ SIKOR. UiT The Arctic University of Norway and the Norwegian Saami Parliament's Saami text collection. Version 01.03.2015. <http://gtweb.uit.no/korp/> Spiik, Nils Eric (1989) Lulesamisk grammatik. Luleå: Th. Blaasvær.

Tuolja, Karin and Susanna Angéus Kuoljok (1999) Giellaj hilá. Jokkmokk: Samisk utbildningscentrum.

Tuolja, Lars Matto (1987) Tjaktjalasta. Jokkmokk: Sámi Girjjit.

Vars, Elle Márjá (2002) Čábbámus iđitguovssu. Indre Billefjord: Iđut.

Vars, Elle Márjá (2004) Tjáppemus idedisguovsoj. Julevsábmáj: Birgit Andersen ja Gøran Andersen. Indre Billefjord: Iđut.

Wickman, Bo (1980) "Features of dialect mixture in the Lappish dialect of Northern Gällivare”. In Osmo Ikola. Congressus Quintus Internationalis Fenno-Ugristarum. Turku 20.-27. VIII 1980. Pars III, Dissertationes symposiorum linguisticorum, 267-272. Turku.

Wiklund, K. B. (1890) Lule-lappisches Wörterbuch. Helsinki: Suomalais-Ugrilaine Seura.

Wiklund, K. B. (1891) Laut- und Formenlehre der Lule-Lappischen Dialekte. Stockholm.

Wiklund, K. B. (1915) Lärobok i lapska språket. Andra, reviderade upplagan. Uppsala: Akademiska bokhandeln. 


\section{Jussi Ylikoski}

Wilbur, Joshua (2014) A grammar of Pite Saami. Berlin: Language Science Press. Ylikoski, Jussi (2004) "Zu den adverbialen Nominalkonstruktionen im Nordsaamischen II. Finale Konstruktionen”. Finnisch-Ugrische Forschungen 58, 57-161.

Ylikoski, Jussi (2009) Non-finites in North Saami. Helsinki: Finno-Ugrian Society.

Kokkuvõte. Jussi Ylikoski: Tuleviku väljendamise vahendid Lule saami keeles mõnede märkustega soome keele kohta. Käesolevas artiklis antakse ülevaade tuleviku väljendamise vahenditest Lule saami keeles. Kuigi varasemad ülevaated kinnitavad, et Lule saami galggat ('pidama, kavatsema') on tuleviku abiverb, on keeles ka kaks teist võimalikku kandidaati, mida võiks samuti nimetada grammatiliseks tulevikuks. Tegeliku keelekasutuse põhjal on näha, et nn potentsiaal ehk võimalikkuse kõneviis Lule saami keeles ei väljenda alati olukordasid ebakindlana või ainult võimalikuna, vaid seda kasutatakse ka tulevikule viitamiseks ilma selge võimalikkuse või teiste modaalsuste tähenduseta. Erilist tähelepanu leiab artiklis teine grammatiseerunud tarind, perifrastiline vorm, mis koosneb koopulast liehket ('olema') ning nn supiinist ehk finaalsest konverbist. Viimaks juhitakse tähelepanu aspektile, et Lule saami keele supiintarindil on formaalne ja funktsionaalne analoog soome keeles, mille finaalse konverbi futuurisarnaseid aspektuaalseid ülesandeid pole varem kirjeldatud.

Märksõnad: tulevik, tuleviku väljendamise vahendid, konverbid, võimalikkuse kõneviis, prospektiivne aspekt, Lule saami keel, soome keel 